\title{
PENAMPILAN PRODUKSI TERNAK BABI GROWER SAMPAI FINISHER YANG MENGGUNAKAN TEPUNG LIMBAH IKAN CAKALANG SEBAGAI PENGGANTI SEBAGIAN KONSENTRAT DALAM RANSUM
}

\author{
Rifal H. Saud, Vonny R.W. Rawung, Jeanette M. Soputan, Mien Th. R. Lapian
}

Fakultas Peternakan Universitas Sam Ratulangi, Manado 95115

\begin{abstract}
ABSTRAK
Penelitian ini bertujuan untuk mengetahui sampai sejauh mana pengaruh pengunaan tepung limbah ikan sebagai pengganti sebagian konsentrat dalam pakan terhadap penampilan produksi ternak babi fase grower sampai finiser. Ternak babi merupakan salah satu ternak penghasil daging yang dapat memenuhi kebutuhan protein hewani, ternak babi sangat potensial dikembangkan di Sulawesi Utara karena memiliki sifat-sifat dan kemampuan yang menguntukan antara lain laju pertumbuhan yang cepat, jumlah anak per kelahiran yang tinggi, efisiensi ransum yang baik dan persentase karkas yang tinggi. Limbah ikan merupakan salah satu bahan pakan yang potensial digunakan sebagai bahan pakan ternak karena muda didapatkan dan harganya yang relatif murah, limbah ikan dapat di olah menjadi tepung ikan dan dapat dimanfaatkan untuk campuran makanan ternak seperti babi, unggas, dan ikan.

Penelitian ini dilaksanakan di peternakan bapak Cloudio Lumowa, diawali dengan pra percobaan selama 2 minggu selanjutnya pengumpulan data mulai pada tanggal 14 juni sampai 26 agustus 2017, menggunakan ternak babi betina dan jantan 20 ekor dengan berat badan 53 - $63 \mathrm{~kg}$. Rancangan penelitian yang digunakan pada percobaan ini adalah Rancangan Acak Kelompok (RAK) dengan 4 perlakuan dan 5 kelompok sebagai ulangan. Perlakuan yang diberikan pada
\end{abstract}

\footnotetext{
*Korespondensi (corresponding author):
} Email: vonny_rawung@yahoo.com pemberian makanan adalah $\mathrm{R} 0=$ ransum yang tidak mengunakan limbah ikan, $\mathrm{R} 1=$ ransum + limbah ikan 2\%, R2= ransum + limbah ikan 4\%, R3 = rasum $+6 \%$ limbah ikan. Hasil analisis menunjukan bahwa pengunaan limbah tepung ikan dengan level 2\%, 4\%, dan 6\% memberikan pengaruh nyata $(\mathrm{P}>0,05)$ terhadap pertambahan berat badan babi dan efisiensi pengunaan pakan, sedangkan komsumsi pakan tidak berpengaruh nyata $(\mathrm{P}<0.05)$. Berdasarkan hasil penelitian dan pembahasan semua variabel dapat disimpulkan bahwa pengunaan tepung limbah ikan cakalang sebagai pengganti sebagian konsentrat sampai dengan $6 \%$ pada babi grower sampai finiser menghasilkan pertambahan bobot badan dan efisiensi penggunaan ransum yang baik.

Kata Kunci: Limbah cakalang, produksi, babi grower.

\section{ABSTRACT \\ PRODUCTION PERFORMANCE OF GROWING PIGS FED RATION CONTAINING CAKALANG FISH WASTE PRODUCT. The study aims to determine the extent of the effect of using fish waste flour as a partial substitute for concentrates in feed on the appearance of grower phase pig production to finiser. Swines are very potential to be developed in North Sulawesi because they have the attributes and capabilities of fast growth rates, high number of litter size, good ration efficiency, and a high percentage of}


carcass. Cakalang fish waste is one of the feed ingredients that are potentially used as animal feed ingredients because it is easy to be obtained and its price is relatively cheap. Cakalang fish waste can be processed into fish meal and can be used for animal feed mixtures including swines, poultry and fishery. This research was carried out on the farm belongs to Mr. Cloudio Lumowa, starting with the pre-trial for the 2 weeks and data collection for the 10 weeks, starting on June 14 to August 26, 2017. Research was using 20 heads of gilt and boar with a range body weight of $53-63 \mathrm{~kg}$. The research design used was Randomized Block Design (RCBD) involving 4 treatments and 5 replications at each treatment. The treatments of feeding were including $\mathrm{R} 0=$ ration without cakalang fish waste flour, $\mathrm{R} 1=$ ration $+2 \%$ cakalang fish waste flour, $\mathrm{R} 2=$ ration $+4 \%$ cakalang fish waste flour, and $\mathrm{R} 3=$ ration $+6 \%$ cakalang fish waste flour. The results of the research showed that the use of cakalang fish waste flour with a level of $2 \%, 4 \%$, and $6 \%$ had a significant effect $(\mathrm{P}<0.05)$ on swine weight gain and feed effciciency, but did not affect significantly feed consumption. Based on the results of the study and discussion of all variables, it can be concluded that the use of cakalang fish waste flour as a partial replacement of concentrate up to $6 \%$ in grower to finisher produced the same ration consumption, a good body weight gain and feed efficiency.

Keywords: cakalang fish waste, production, grower

\section{PENDAHULUAN}

Peternakan mempunyai peranan penting dalam menunjang kebutuhan masyarakat sebagai sumber bahan makanan dalam bentuk protein hewani. Bertambahnya jumlah penduduk dan meningkatnya kesadaran akan pentingnya nilai protein hewani bagi kesehatan, mengakibatkan meningkatnya kebutuhan akan protein hewani namun hal ini tidak diimbangi dengan laju peningkatan produksi ternak khususnya ternak babi.

Ternak babi merupakan salah satu dari sekian jenis ternak yang mempunyai potensi sebagai suatu sumber protein hewani, dan juga baik untuk dikembangkan (Tumbelaka, 2007). Keistimewaan dari ternak babi ialah relatif muda dipelihara dan sebagai ternak yang tergolong prolifik artinya beranak dalam jumlah banyak. Dalam setahun babi mampu menghasilkan anak perkelahiran berkisar 8-12 ekor dengan rata-rata 2 kali kelahiran per tahunnya. Selain itu ternak babi memiliki potensi besar untuk dikembangkan karena memiliki sifat dan kemampuan yang menguntungkan antara lain laju pertumbuhan yang cepat, jumlah anak per kelahiran (litter size) yang tinggi, efisiensi ransum yang baik dan persentase karkas yang tinggi. Selain itu ternak babi mampu mengkonversi berbagai sisa pertanian dan limbah restoran menjadi daging yang bermutu tinggi (Siagian, 2003).

Salah satu faktor yang menentukan keberhasilan usaha peternakan babi adalah ransum yang mengandung zat-zat makanan yang imbangan nutrisinya baik atau sempurna dan sesuai dengan kebutuhan ternak. Menurut (NRC, 2008), kebutuhan 
zat makanan ransum babi periode finisher yaitu energy metabolisme sebanyak 3200 kkal, protein kasar sebanyak 13\%, kandungan serat kasar ransum sebesar 5\%, lemak $1-5 \%$.

Konsentrat adalah campuran beberapa bahan pakan yang disusun untuk membuat ransum komplit serta zat makanannya seimbang. Konsentrat merupakan salah satu bahan pakan penyusun ransum ternak yang dapat diberikan sebagai bahan pakan ternak babi walaupun harganya relative mahal. Oleh karena itu usaha mencari dan meneliti bahan lain yang diduga dapat menganti sebagian atau seluruh konsentrat dalam ransum merupakan salah satu upaya pemecahan bila kekurangan konsentrat di pasaran. Bahan pakan yang di madsud tentunya mempunyai gizi yang minimal berimbang dengan konsentrat, murah, tidak bersaing dengan kebutuhan manusia dan tidak menggangu kesehatan ternak yang mengkomsumsinya.

Sulawesi Utara adalah salah satu daerah penghasil ikan terbesar di Indonesia. Perairan Sulawesi Utara terkenal dengan produksi Ikan Cakalang (Katsuwonus Pelamis L), Data dari Dinas Perikanan Provinsi Sulawesi Utara produksi ikan cakalang tahun 2009 sebesar 60.890 ton, tahun 2010 sebesar 60.168 ton. Di Sulawesi Utara cukup terkenal sebagai daerah yang memiliki industri pengolahan hasil perikanan berskala ekspor berupa industri ikan kaleng, ikan kayu, dan ikan asap yang umumnya jenis ikan pelagis besar atau kecil seperti tuna, cakalang, deho yang digunakan. Berkembangnya industri pengolahan ikan ini berdampak pada melimpahnya limbah ikan yang sesunggunya masih dapat dimanfaatkan sebagai bahan baku tepung ikan. Limbah yang dihasilkan dari kegiatan perikanan adalah limbah bentuk padat berupa potongan daging ikan, sisik, dan insang. Limbah ikan yang berbentuk cair antar lain darah, lendir dan air cucian. Sedangkan limbah ikan yang berbentuk gas adalah bau yang dihasilkan karena senyawa amonia, hidrogen sulfida atau keton. Secara umum produksi limbah ikan cakalang tergantung pada proses pengolahan industri dan bagian by product atau limbah adalah bagian jeroan, insang, daging coklat, kepala, tulang, dan kulit. Potensi limbah ikan memberikan peluang yang sangat besar untuk dimanfaatkan sebagai salah satu bahan pakan pengganti sebagian konsentrat dalam pakan ternak babi.

Berdasarkan latar belakang tersebut maka telah dilaksanakan suatu pencobaan yang bertujuan untuk mengetahui sampai sejauh mana pengaruh pengunaan tepung limbah ikan sebagai pengganti sebagian konsentrat dalam pakan terhadap penampilan produksi ternak babi fase grower sampai finiser. 


\section{MATERI DAN METODE PENELITIAN}

Penelitian ini mengunakan 20 ekor ternak babi fase grower sampai finiser (13 ekor jantan kastrasi dan 7 betina) hasil persilangan yorkshire dan duroc berumur 17 - 29 minggu dengan kisaran bobot badan 53 - 63 kg. Kandang yang digunakan pada penelitian ini adalah kandang individual dengan ukuran 180 x 50 x $90 \mathrm{~cm}$ sebanyak 20 unit yang dilengkapi dengan tempat makan ukuran $40 \times 40 \mathrm{~cm}$ dan tempat minum dari niple.
Ransum yang digunakan selama penelitian hampir semuanya diperoleh dari peternakan di tempat penelitian kecuali tepung limbah ikan. Pemberian pakan ad libitum.

Bahan pakan penyusun ransum terdiri dari tepung limbah pengalengan ikan, jagung, dedak halus, kosentrat. Penggunaan tepung limbah pengalengan ikan yang diambil dari pabrik ikan di Amurang yang sudah dikeringkan. Komposisi zat zat makanan dan energi metabolis bahan pakan penyusun ransum tercantum pada Tabel 1 dan 2.

Tabel 1. Susunan Bahan Pakan

\begin{tabular}{lrcrr}
\hline Bahan Pakan & Perlakuan & R2 & R3 \\
\hline Jagung (\%) & 60 & 60 & 60 & 60 \\
Dedak (\%) & 20 & 20 & 20 & 20 \\
Kosentrat (\%) & 20 & 18 & 16 & 14 \\
Tepung Limbah Ikan & 0 & 2 & 4 & 6 \\
cakalang (\%) & 100 & 100 & 100 & 100 \\
Total & & & & \\
\hline
\end{tabular}

Tabel 2. Kandungan ZaT-Zat Bahan Pakan Penelitian

\begin{tabular}{lrrrrrr}
\hline \multicolumn{1}{c}{ Bahan Pakan } & $\begin{array}{r}\text { Protein } \\
(\%)\end{array}$ & $\begin{array}{r}\text { Lemak } \\
(\%)\end{array}$ & $\begin{array}{r}\text { Serat } \\
\text { Kasar }(\%)\end{array}$ & $\begin{array}{r}\text { Ca } \\
(\%)\end{array}$ & $\begin{array}{r}\mathrm{P} \\
(\%)\end{array}$ & $\begin{array}{r}\text { Energi } \\
(\mathrm{Kkal} / \mathrm{Kg})\end{array}$ \\
\hline Jagung* & 9,42 & 5,17 & 2,15 & 0,22 & 0,60 & 3,182 \\
Dedak**** & 12,9 & 0,7 & 11,4 & 0,7 & 1.5 & 2,875 \\
Kosentrat** & 39 & 3 & 6 & - & 0,06 & 3,200 \\
tepung limbah & 40,66 & 4,47 & 1,58 & 5,9 & 1,62 & 4,049 \\
ikan cakalang*** & & & & & & \\
\hline
\end{tabular}

Sumber * Hasil Analisa Dengah et al, 2016

** Hasil Analisa PT Cargil Indonesia

*** Hasil Analisa Lab Ilmu dan Teknologi Pakan IPB Bogor 2017

**** Hasil Analisa Tatilu et al, 2014 
Tabel 3. Komposisi Zat-Zat Bahan Pakan Penelitian

\begin{tabular}{lrrrr}
\hline $\begin{array}{l}\text { Komposisi pakan } \\
\text { Penelitian }\end{array}$ & R0 & R1 & R2 & R3 \\
\hline Protein (\%) & 16,03 & 16,06 & 16,09 & 16,13 \\
Lemak (\%) & 3,84 & 3,87 & 3,90 & 3,93 \\
Serat Kasar (\%) & 4,77 & 4,68 & 4,59 & 4,50 \\
Ca (\%) & 0,27 & 0,39 & 0,50 & 0,62 \\
Phosphor (\%) & 0,78 & 0,80 & 0,82 & 0,84 \\
Energi Metabolik (kkal) & 3004,80 & 3021,78 & 3038,76 & 3055,74 \\
\hline
\end{tabular}

Metode Penelitian

Penelitian ini mengunakan Rancanngan Acak Kelompok ( Steel and torrie,1995) dengan 4 macam pakan (RO, $\mathrm{R} 1, \mathrm{R} 2$, dan R3) sebagai perlakuan dan 5 kelompok ternak babi sebagai ulangan setiap kelompok terdir dari 4 ekor.

Penelitian ini mengunakan 4 perlakuan dan 5 ulangan, sehingga jumlah ternak babi yang akan digunakan sebanyak 20 ekor. Susunan ransum perlakuan adalah: RO $=$ Kosentrat $20 \%+$ Tepung Limbah Ikan Cakalang 0\%

$\mathrm{R} 1=$ Kosentrat $18 \%+$ Tepung Limbah Ikan Cakalang 2\%

$\mathrm{R} 2=$ Kosentrat $16 \%+$ Tepung Limbah Ikan Cakalang 4\%

R3 = Kosentrat $14 \%+$ Tepung Limbah Ikan Cakalang 6\%

Kelompok berat badan :

$$
\begin{array}{ll}
\text { Kelompok I } & =53-55 \mathrm{Kg} \\
\text { Kelompok II } & =55-57 \mathrm{Kg} \\
\text { Kelompok III } & =57-59 \mathrm{Kg}
\end{array}
$$

Kelompok IV $=59-61 \mathrm{Kg}$

Kelompok V $=61-63 \mathrm{Kg}$

\section{Prosedur Penelitian}

Krangkeng di timbang sebelum digunakan, setelah itu babi dimasukan kedalam krangkeng untuk ditimbang. Kemudian babi di masukan kedalam kandang penelitian secara acak.

\section{Pemberian ransum}

ransum diberikan ad libitum setiap hari sedikit demi sedikit agar tidak terbuang. Ransum sisa ditimbang pagi hari sebelum kandang dibersikan dan sebelum pemberian ransum yang baru.

Limbah ikan diambil pada perusahaan PT Nichindo Kabupaten Minahasa Selatan. Perusahaan Industri ikan ini, menghasilkan limbah padat dan cair. Penelitian ini mengunakan limbah padat yang terdiri kepala, daging merah, tulang, jeroan, sirip. Diagram alir dapat di lihat pada gambar 1 


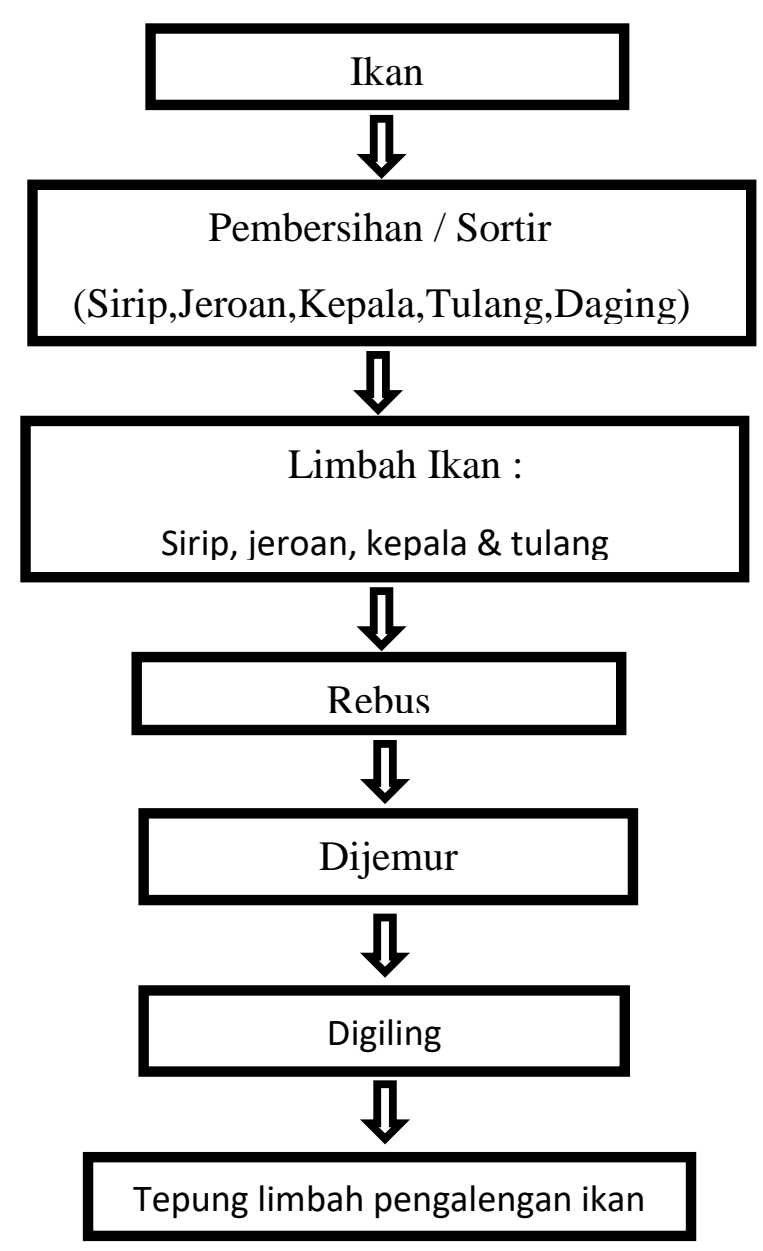

Gambar 1 : Proses Pembuatan tepung limbah ikan cakalang

\section{Variabel penelitian}

\section{Pertambahan berat badan}

Pertambahan berat badan yaitu jumlah (kg), yang diperoleh dari selisih antara penimbangan berat badan awal dan berat badan akhir. (penimbangan berat badan setiap 2 minggu).

\section{Konsumsi ransum}

Konsumsi ransum $(\mathrm{kg})$ per ekor ternak babi per hari jumlah ransum yang diberikan dikurangi dengan jumlah ransum sisa.

\section{Efisiensi pengunaan ransum}

Efisiensi penggunaan ransum adalah jumlah konsumsi ransum dibagi dengan pertambahan berat badan dalam waktu yang sama mengikuti penimbangan. 


\section{HASIL DAN PEMBAHASAN}

\section{Pengaruh Perlakuan Terhadap Pertambahan Berat Badan}

Pertambahan berat badan merupakan salah satu parameter pengukuran performans yang diukur pada penelitian ini. Rataan hasil penelitian R0, R1, R2 dan R3 yaitu $0,53,0,66,0,68$ dan 0,70 (Tabel 4) memperlihatkan pertambahan berat badan terus meningkat dengan bertambanya level tepung limbah ikan cakalang dalam ransum, hasil penelitian ini lebih tinggi dari yang direkomendasikan oleh Siagian (2005) bahwa rataan pertambahan berat badan 0,57 - 0,64.Hasil analisis sidik ragam menunjukan bahwa pengunaan tepung limbah ikan cakalang sebagai pengganti sebagian konsentrat memberikan pengaruh yang berbeda nyata $(\mathrm{P}>0,05)$ terhadap pertambahan berat badan. Hal ini disebabkan karena kandungan protein dan energi dari limbah ikan cakalang yang tinggi dilihat dari (Tabel 4) sehingga menyebabkan terjadinya perbedaan dalam pertambahan berat badan.
Hasil uji lanjut BNT menunjukan bahwa penggunaan tepung limbah ikan cakalang dalam ransum babi R0 (0\%) berbeda nyata dibandingkan dengan pertambahan berat badan R1 (2\%), R2(4\%) dan R3 (6\%) dan sedangkan pertambahan berat badan R3 (6\%) berbeda nyata dengan $\mathrm{R} 1(2 \%)$ tetapi tidak berbeda nyata dengan R2 (4\%). Hal ini berarti bahwa pertambahan berat badan ternak babi semakin meningkat dengan bertambahnya level ikan cakalang $4-6 \%$, hal ini dapat dijelaskan bahwa tepung ikan yang merupakan sumber protein serta komposisi asam amino esensial yang baik terutama lysine. Sebagaimana diketahui bahwa lysine merupakan faktor pembatas utama "first limiting factor" untuk pemenuhan kebutuhan akan asam amino dari ternak babi (Patience et al., 1995). Oleh sebab itu semakin tinggi level tepung ikan dalam ransum menyebabkan peningkatan protein yang mengarah pada peningkatan kualitas ransum sehingga kandungan energi juga terus meningkat dengan meningkatnya level tepung limbah ikan cakalang

Tabel 4. Rataan Pertambahan Berat Badan, Konsumsi Ransum, Efisiensi Penggunaan Ransum

\begin{tabular}{lcccc}
\hline \multirow{2}{*}{\multicolumn{1}{c}{ variabel }} & \multicolumn{4}{c}{ Perlakuan } \\
\cline { 2 - 5 } & $\mathrm{R}_{0}$ & $\mathrm{R}_{1}$ & $\mathrm{R}_{3}$ & $\mathrm{R}_{4}$ \\
\hline Pertambahan Berat Badan & $0,53^{\mathrm{a}}$ & $0,66^{\mathrm{b}}$ & $0,68^{\mathrm{b}}$ & $0,70^{\mathrm{b}}$ \\
Konsumsi Ransum & 2,81 & 2,79 & 2,69 & 2,67 \\
Efisiensi Pengunaan Ransum & $0,19^{\mathrm{a}}$ & $0,24^{\mathrm{b}}$ & $0,26^{\mathrm{b}}$ & $0,27^{\mathrm{b}}$ \\
\hline
\end{tabular}

Ket: Superskrip huruf yang berbeda pada baris menunjukkan hasil berbeda nyata $(\mathrm{P}>0,05)$ 
menyebabkan pertambahan berat badan meningkat. Didalam pembentukan daging pada masa pertumbuhan ternak babi membutuhkan asupan protein dan energi yang sesuai dengan kebutuhan ternak (Tulung, 2015), kebutuhan nutrien terutama protein untuk ternak babi erat kaitannya dengan ketersediaan energi. Energi memegang peranan penting dalam aktifitas kehidupan ternak untuk hidup pokok, gerak otot dan pembentukan sel-sel jaringan baru membutuhkan energy (Tamawiwi et al., 2016).

\section{Pengaruh Perlakuan Terhadap Komsumsi ransum}

Rataan komsumsi ransum ternak babi pada penelitian yang menggunakan bahan tepung limbah ikan cakalang adalah $2,81-2,67 \mathrm{~kg} /$ ekor/hari dengan rataan 2,74 kg. Jumlah konsumsi ransum pada penelitian ini masih dalam kisaraan yang direkomendasi oleh (Sihombing, 2006) yaitu $1,5-2,75 \mathrm{~kg}$. Hasil analisis sidik ragam menunjukan bahwa pemberian tepung limbah ikan cakalang dalam ransum memberikan pengaruh yang tidak berbeda nyata $(\mathrm{P}<0,05)$ terhadap komsumsi ransum. Hal ini disebabkan karena umur, lingkungan dan kandungan zat-zat makanan dari semua ransum percobaan hampir sama. Walaupun konsumsi ransum tidak berbeda namun dari data dapat dilihat bahwa semakin tinggi level tepung ikan dalam ransum, konsumsi ransum cenderung menurun, hal ini dapat dijelaskan bahwa semakin tinggi level tepung ikan, maka kandungan energi dalam ransum semakin tinggi, sedangkan konsumsi ransum menurun. Kandungan energi ransum secara umum akan mengontrol jumlah konsumsi. Hal ini sesuai dengan pernyataan Church (1979) yang dikutip oleh Sinaga (2002) bahwa tinggi rendahnya konsumsi ransum secara umum dipengaruhi oleh palatabilitas dan energi yang terkandung dalam ransum. Angorodi, (1994) menyatakan bahwa konsumsi ransum cenderung meningkat bila kandungan energi menurun, dan sebaliknya jumlah komsumsi ransum akan berkurang bila kandungan energi tinggi. Salah satu aspek yang menentukan tinggi rendahnya kualitas ransum adalah kandungan protein, energi, vitamin, mineral dan bahan-bahan lain yang menunjang pertumbuhan dan proses pencernaan biologis (Sinaga dan Martini, 2010).

\section{Pengaruh Perlakuan Terhadap Efisiensi Penggunaan ransum}

Efisiensi penggunaan ransum merupakan salah satu parameter pengukuran performans yang diukur pada penelitian ini. Rataan hasil penelitian R0, $\mathrm{R} 1, \mathrm{R} 2$ dan R3 yaitu 0,19, 0,24, 0,26 dan 0,27 (Tabel 4) memperlihatkan rataan 
efisiensi penggunaan ransum terus meningkat dengan bertambahnya level tepung limbah ikan cakalang dalam ransum. Penggantian sebagian konsentrat dengan tepung limbah ikan cakalang $2 \%$ $6 \%$ meningkatkan kadungan zat-zat makanan terutama protein ransum.

Hasil analisis sidik ragam menunjukan bahwa pengunaan tepung limbah ikan cakalang memberikan pengaruh yang berbeda nyata $(\mathrm{P}>0.05)$ terhadap efisiensi pengunaan ransum. Uji lanjut dengan uji BNT menunjukan bahwa R0 (0\% tanpa tepung limbah ikan cakalang) berbeda nyata dengan perlakuan R1 (2\%), R2 (4\%) dan R3 (6\%). Hal ini dapat diartikan bahwa pengunaan tepung limbah ikan cakalang dari 2\% - 6\% mempengaruh efisiensi penggunaan ransum ternak babi fase grower sampai finisher. Hasil diatas mengindikasikan bahwa semakin tinggi level tepung limbah ikan cakalang dalam ransum menaikan angka efisiensi pengunaan ransum. Nilai efisiensi yang tinggi menunjukan bahwa bahan makanan yang dikonsumsi mengandung zat-zat makanan yang baik sehingga sangat efisien untuk diubah menjadi daging, sebaliknya nilai efisiensi yang rendah menunjukan bahan makanan kurang efisien untuk diubah menjadi daging. Tepung limbah ikan cakalang yang diberikan pada penelitian ini mengandung protein terutama lysin sangat mendukung pertumbuhan ternak babi, sehingga efisiensi penggunaan ransum baik. Anggorodi (1994) menyatakan bahwa efisiensi penggunaan ransum dipengaruhi oleh faktor konsumsi, daya cerna dan penggunaan zat-zat makanan. Rumerung (2015) dan Sinaga (2009) menyatakan bahwa efisiensi penggunaan ransum berkaitan erat dengan rataan pertambahan berat badan harian dan konsumsi ransum.

\section{KESIMPULAN}

Berdasarkan hasil penelitian dan pembahasan semua variabel dapat disimpulkan bahwa pengunaan tepung limbah ikan cakalang sebagai pengganti konsentrat sampai dengan $6 \%$ pada babi grower sampai finiser menghasilkan pertambahan bobot badan dan efisiensi penggunaan ransum yang baik.

\section{DAFTAR PUSTAKA}

Anggorodi, R. 1990. Ilmu Makanan Ternak Umum. Penerbit PT Gramedia, Jakarta. Universitas Indonesia Press.

Church, D.C. 1979. Factor Affecting Feed Consumption. Livestock Feeds and Feeding. Durham and Docuney, Inc. Page 136-139

Dinas Kelauatan dan Perikanan. 2010. Buku Tahunan Statistika Perikanan 
Tangkap Sulawesi Utara. Manado.Provinsi Sulawesi Utara.

Dengah, P.S., J.F. Umboh, C. Rahasia, Y.H.S. Kowel. 2016. Pengaruh pengantian Tepung Ikan dengan Tepung Maggot (Hermitia Illucens) dalam ransum terhadap performans broiler. Jurnal Zootek 36 (1):51-60

NRC, 1988. Nutrient Requirments of Swine, $9^{\text {th }}$ Ed. National Academy Press. Washington, DC.

Patience, J. F., P. A. Pearce Thacker and C. F. M. de Large. 1995. Swine Nutrition Guide. 2 nd Ed. Printed in canada pp. 15-31

Rumerung, S, N. 2015. Efek penggunaan konsentrat pabrikan dan buatan sendiri dalam ransum babi starter terhadap efisiensi penggunaan ransum. Jurnal Zootek, 35(2): 295301.

Siagian, P.H., S. Natasasmita, dan P. Silalahi. 2005. Pengaruh substitusi jagung dengan corn gluten feed (cgf) dalam ransum terhadap kualitas karkas babi dan analisis ekonomi. Media Peternakan. Vol.28 (3): 100-108

Siagian, P.H., Muladno dan A. Gurmilang. 2003. Pengaruh Zeolit dan Tepung Darah sebagai Sumber Protein dalam Ransum terhadap Kualitas Karkas Babi. Journal of Indonesia Zeolites. Vol. 2 No.1: 1411-6723

Sihombing, D.T.H. 2006. Ilmu Ternak Babi. Cetakan ke- 2. Gadjah Mada University Press, Yogyakarta.

Sinaga, S dan Sri Martini. 2010. Pengaruh Pemberian Berbagai Dosis Curcuminoid pada ransum babi periode stater terhadap efisiensi ransum. . J. Ilmu Ternak. Vol. 10(2): 95-101.

Sinaga, S. 2002. Performans Produksi Babi Akibat Tingkat Pemberian Manure Ayam Petelur Dan Asam Amino LLisin Sebagai Bahan Pakan Arternatif. Thesis. Unpad. Bandung

Tamawiwi, A., M. Najoan, J. S Mandey. F. N Sompie. 2016. Pengaruh Penggunaan Virgin Coconut Oil (VCO) dalam ransum terhadap performans ternak babi fase starter. Jurnal Zootek Vol. 36(1): 86-94

Tatilu, F.F., F.N. Sompie, M. Imbar, Y.H.S Kowel. 2014. Pengaruh pergantian dedak halus dengan kulit buah kopi terhadap presentase karkas dan lemak abdomen broiler. Jurnal Zootek 35 (2): 267-274

Tulung, C., J. F. Umboh, F. N. Sompie, Ch. J. Pontoh. 2015. Pengaruh penggunaan Virgin Cocobut Oil (VCO) dalam ransum terhadap kecernaan energi dan protein pada ternak babi fase grower. Jurnal Zootek 35(2): 319 - 327

Tumbelaka, L.I.T.A dan Siagian P.H. 2007. Pengaruh sistem dan paritas terhadap penampilan reproduksi babi di PT Adhi Farm Solo. J. Ilmu Ternak. Vol. 7(2): 145-148 